\title{
Review of the concept of quality in Hass avocado and the pre-harvest and harvest factors that determine it under tropical conditions
}

\section{Revisión del concepto de calidad en aguacate Hass y los factores pre-cosecha y cosecha que la determinan bajo condiciones tropicales}
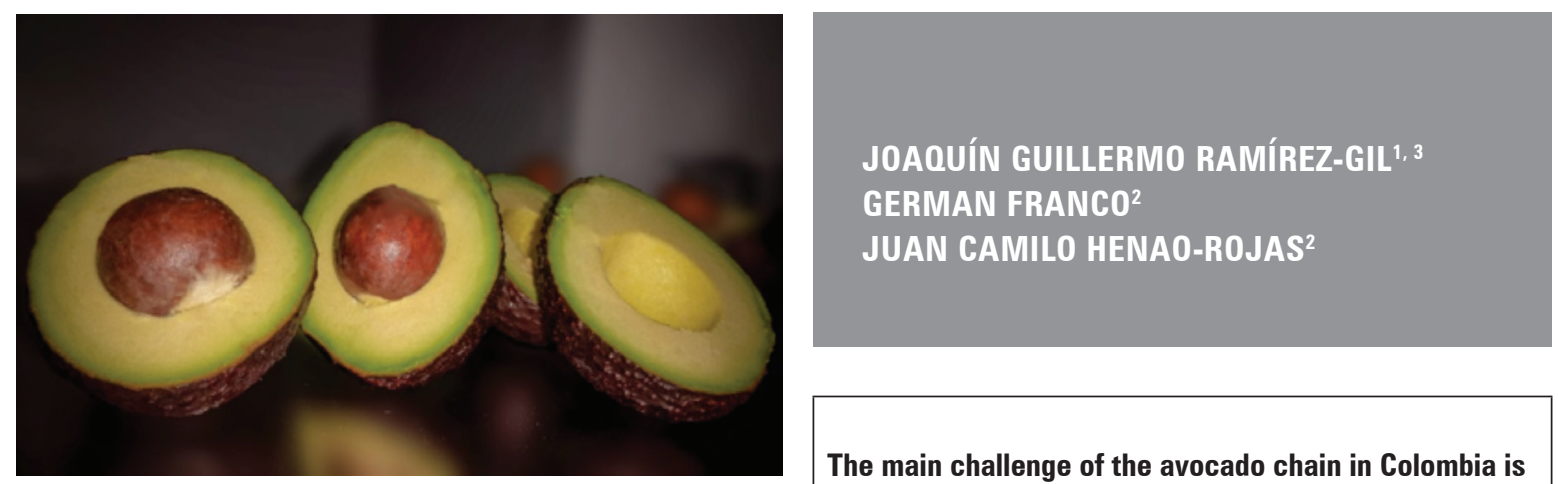

The main challenge of the avocado chain in Colombia is to produce quality.

Photo: J.C. Henao-Rojas

\section{ABSTRACT}

Avocado is one of the most desirable fruits worldwide because of its flavor and nutritional contributions. Currently, Colombia is a very dynamic country where the cultivated area and volumes of exported fruits have been increasing year after year. This situation poses a challenge for the country, which must produce fruits with excellent parameters of ripening, external and internal quality. This study used a series of elements associated with quality in avocado and its application in tropical conditions, which were determined based on reports from the world scientific literature reported in journals, books, manuals and conferences. In addition, information obtained from commercial esays on plantations and the experiences of packing and marketing companies in Colombia was used. The approach presented here is associated with a modern concept of quality in the food industry and how it can be applied to the avocado value chain; preharvest aspects that determine quality, management practices conducive to improving quality, and harvest parameters and their relationship with quality were also used. This study generated alternatives for increasing the added value in the avocado production system based on quality parameters and identified delays in the supply chain of this important agro-industry under tropical conditions.

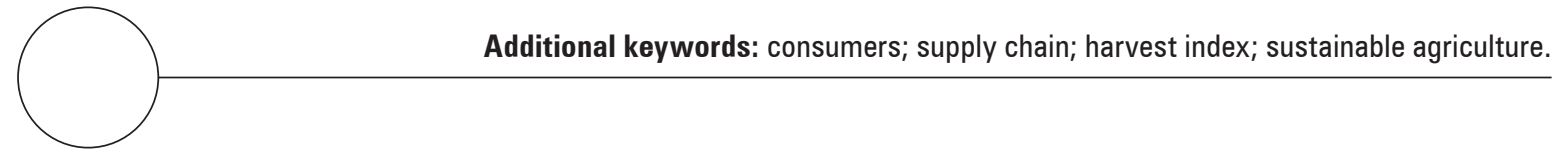

Universidad Nacional de Colombia, Facultad de Ciencias Agrarias, Departamento de Agronomía, Bogota (Colombia). ORCID Ramírez-Gil, J.G.: 0000-0002-0162-3598

2 Corporación Colombiana de Investigación Agropecuaria (Agrosavia), Centro de Investigacion La Selva, Rionegro (Colombia). ORCID Franco, G.: 0000-0002-0162-3598; ORCID Henao-Rojas, J.C.: 0000-0003-0007-6809

3 Corresponding author. jgramireg@unal.edu.co 


\section{RESUMEN}

El aguacate es una de las frutas más deseables en todo el mundo debido a su sabor y aportes nutricionales. Colombia es un país muy dinámico, donde el área plantada y los volúmenes de fruta exportada han ido creciendo año tras año. Esta situación plantea un desafío para el país, que debe producir en función de la calidad, logrando posicionar una fruta con excelentes parámetros de maduración, calidad externa e interna. En este trabajo, se presentan una serie de elementos asociados con la calidad del aguacate y su aplicación a las condiciones tropicales, que se determinaron con base en reportes de la literatura científica mundial como revistas, libros, manuales y conferencias. Además, utilizamos información obtenida a través de ensayos comerciales de plantaciones y experiencias de empresas de empaque y comercialización en Colombia. El enfoque presentado aquí está asociado con un concepto moderno de calidad en la industria alimentaria y cómo se puede aplicar a la cadena de valor del aguacate, también presentamos aspectos de cosecha y poscosecha que determinan la calidad y prácticas de manejo conducentes a mejorar la calidad. Este trabajo genera alternativas para aumentar el valor agregado en el sistema de producción de aguacate con base en parametros de calidad e identifica los retrasos de la cadena de valor de esta importante agroinustria bajo condiciones tropicales.

Palabras clave adiconales: consumidores; cadena de suministro; índice de cosecha; agricultura sostenible.

Received for publication: 08-11-2019 Accepted for publication: 29-11-2019

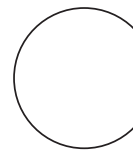

INTRODUCTION

Avocado, especially the Hass variety, has grown significantly in planted areas in Colombia, leading to increases in production and exported volumes (Ramírez-Gil et al., 2018). This growth is supported by a higher domestic demand and mainly by the boom in exports, especially to the European Union. Thus, the country went from exporting $3 \mathrm{t}$ in 2005 to $30,008 \mathrm{t}$ in 2018 (MADR, 2018). There is currently great expectation for the possibility of exporting fruit to other countries such as Japan, The United Arab Emirates, The United States, Canada, and China, among others.

The avocado fruit is very popular and highly consumed in many countries given its high nutritional content of vitamins A, B, C, potassium, phosphorus, magnesium, iron, unsaturated fatty acids, and antioxidants (Araújo et al., 2018). In addition, it has been demonstrated that the consumption of this fruit reduces the risk of cardiovascular diseases, hyperlipidemia, and visceral adipose tissue and contributes to weight control and healthy aging (Duarte et al., 2016).

Fruit and vegetable quality is expressed by different indicators, which cover a large number of organoleptic parameters (e.g. visual appearance, shape, size, color, texture, taste, aroma, etc.), nutritional characteristics (e.g. minerals, proteins, fiber, cofactors, carbohydrates, fatty acids, vitamins, enzymes, coenzymes, etc.), functional properties (e.g. anti-cancer properties and removal of saturated fats, among others), origin (e.g. the way it is produced, place of origin, certificates, etc.), and defects (e.g. mechanical, physical, etc.). Quality is defined, to a large extent, by the final consumer, who sets criteria based on personal preferences and expectations. However, it has a direct relationship with all the actors in the value chain (e.g. producers, packers, transporters, and traders).

The Hass avocado production system does not currently have a validated technological model for the Colombian tropics, a situation that increases uncertainty in production. Fruit production must ensure delivery of an excellent quality product to the market that meets the international standards set by importing countries, taking into account agronomic aspects such as cultivation, harvest, post-harvest, logistics, storage, and marketing. For this reason, the objective of Colombia, as an avocado producer, should be the production of fruit of the highest quality in order to position the country and the Colombian avocado brand in markets worldwide.

Thus, it is important to determine the basic quality criteria for Colombian avocado, which should be defined from the consensus among producers, packers, traders, and consumers. Having specific quality 
standards may help chain stakeholders to perceive these benefits in monetary terms as they seek to increase profitability and sustainability. In addition, consumers can obtain all the benefits in terms of organoleptic, nutritional and functional quality that this fruit can provide.

This manuscript aimed to introduce a concept of quality and define the basic pre-harvest and harvest parameters that determine Hass avocado quality. This review was carried out based on the information reported by different sources such as scientific papers, proceedings from seminars, congresses, and technology transfer events. In addition, data provided by producer farms and the experience of Colombian technical assistants and traders were considered, also previous validation of the information and analysis of the results. The approach presented here was carried out in chapters in which the following topics: (i) quality concepts and application to the avocado industry and its production systems, (ii) preharvest aspects that determine quality and management practices conducive to improving quality, and (iii) harvest parameters and their relationship with quality.

\section{GENERAL PARAMETERS ASSOCIATED WITH QUALITY IN THE FOOD INDUSTRY AND THEIR RELATIONSHIP WITH THE AVO- CADO FRUIT}

\section{Definition of quality}

In the case of the avocado market, the quality requirements for exported fruits are completely different from the ones for fruit for domestic consumption. Similarly, differentiated properties are required for the production of avocado pulps for the pharmaceutical industry (content of polyunsaturated fatty acids, vitamin $\mathrm{E}$, avocatin $\mathrm{B}$, terpenes, phytosterols, and antioxidant activity, etc.) (Sarkar et al., 2017). There are different characteristics that make a specific market interested in a particular concept of quality. This idea was developed by the International Organization for Standardization, which created the currently accepted definition of quality as "the ability of a product or service to meet the declared or implied needs of the consumer through its properties or characteristics" (Singels et al., 2001). Accordingly, in every production chain, suppliers, intermediaries, and traders must know their market (needs and expectations) in detail in order to generate differentiated qualities for specific customers (Orjuela-Castro et al., 2017), a rare action in Colombian production economies.

\section{Concept of multidimensional quality}

The concept of multifunctional or multidimensional quality has been a trend since the end of the $20^{\text {th }}$ century. In this theory, the perception of quality should be the result of the interrelation of several components, which can be measured, classified and weighted according to the level of importance given by end customers and some intermediaries of the value chain (Prieto et al., 2008; Liverani et al., 2019).

The components of the multidimensional quality "function" can be classified into two large groups. Firstly, the incorruptible and basic elements of the product or those aspects that are decisive for the product to be accepted. Secondly, and equally important, are the so-called "surprise" aspects. These are characteristics that, although final customers do not expect to find them a priori, once they are perceived they are appreciated and considered as added value. In the case of avocado, this type of quality criterion would include the nutritional and sensory characteristics that stand out in fruits. Such characteristics are a better trans/cis ratio of fatty acids (Serpa et al., 2014) or some unusual aroma and flavor tones in ripe fruits (Obenland et al., 2012). Accordingly, for the "Colombian avocado" product, a scalable and specific quality function could be created for the interests of customers, which should include the usage needs and imaginary consumption of target markets.

\section{Quality perception in Hass avocado}

The quality perception characteristics for Hass avocado can be separated into three types: physical, chemical and microbiological. For the physical quality characteristics in Hass avocado, there are a number of factors that could be associated with these parameters. These parameters include polar and equatorial diameters, sphericity index, and peel, pulp and seed percentages, etc. However, the most used criteria in exports and marketing are size and weight, which are currently considered the main quality factors offered by trading companies worldwide (Tab. 1). There is also a series of visual specifications related to physical quality that are currently the basic parameters of fruit selection (Tab. 2). 


\section{Table 1. Hass avocado calibers and their categorization de- pending on the country of consumption for $10 \mathrm{~kg}$ packaging boxes'.}

\begin{tabular}{|l|c|c|c|}
\hline \multicolumn{1}{|c|}{ Europe } & Canada & USA & Colombia \\
\hline Caliber 14 & $>258 \mathrm{~g}$ & 40 & Extra \\
\hline Caliber 16 & $227-258 \mathrm{~g}$ & 48 & Extra \\
\hline Caliber 18 & $227-203 \mathrm{~g}$ & $48-60$ & First \\
\hline Caliber 20 & $203-184 \mathrm{~g}$ & 60 & First \\
\hline Caliber 22 & $184-165 \mathrm{~g}$ & 60 & First \\
\hline Caliber 24 & $<165 \mathrm{~g}$ & 70 & First-Second \\
\hline
\end{tabular}

'Specifications taken from the criteria used by avocado producing, sorting, exporting and distributing companies operating in Colombia.

On the other hand, chemical factors are associated with the metabolic richness of Hass avocado fruits. Among these factors, the lipid profile and triterpene and vitamin E contents are some of the most important in this fruit (Tan et al., 2017). This is important given the new trends of healthy consumption and the reports on the role of unsaturated fatty acids in the decrease of cardiovascular pathologies (Botero and Morales, 2018). Finally, microbiological quality is related to a product's health at the consumption stage. The presence of fungi, molds or yeasts in fruits is an excluding factor for end customers and is one of the most heavily sanctioned by international markets (Tab. 2).

According to Prieto et al. (2008), other ways to classify Hass avocado quality may depend on hygienic, sanitary, bromatological, health, organoleptic and ethical or emotional characteristics. Hygienic-sanitary quality refers to the absence in the food matrix of components that can cause any harm or put consumers' health at risk. These factors can be biotic (pathogens such as bacteria, parasites, viruses, prions, toxins, and allergens) and abiotic (pesticide residues, pesticides, and contaminants, etc.). In the case of the Hass avocado production system, this is considered an exclusion factor for the export market since fruits cannot be used for this purpose if they have agrochemical residues.

Bromatological quality refers to the nutritional quality that a foodstuff provides in terms of macronutrients (carbohydrates, proteins, fats, fiber, and ashes). This quality is one of the most historically appreciated by consumers in previous decades. However, modern markets tend to request more specificity and migrate to health-focused quality (Prieto et al., 2008).

Nowadays, quality focused on health is restricted to the knowledge of any substance that is bioavailable for consumers and that may have some beneficial effect on aspects associated with the prevention and protection of any human pathology. In the case of Hass avocado, its monounsaturated and polyunsaturated fatty acid contents are particularly relevant for consumers given the multiple reports of their effect on chronic non-transmissible pathologies such as metabolic syndrome (Fulgoni et al., 2013), the reduction of dyslipidemia severity in patients with hypercholesterolemia (Lottenberg et al., 2002), or even the

Table 2. Visual quality characteristics and classification in Hass avocado for Colombian traders ${ }^{1}$.

\begin{tabular}{|c|l|l|}
\hline Category & \multicolumn{1}{|c|}{ Characteristic of mandatory compliance } & \multicolumn{1}{|c|}{ Tolerance } \\
\hline Extra & $\begin{array}{l}\text { Fruits at proper ripeness stage, intact and visibly healthy, free of insects, with a } \\
\text { fresh appearance and firm consistency; free of abnormal external moisture, odors, } \\
\text { flavors and foreign materials; free of damage in the epidermis by temperature; fruits } \\
\text { with pedicel }(<5 \mathrm{~cm}) \text { and with minimum values of pesticide residues. }\end{array}$ & $\begin{array}{l}\text { Superficial spots from lenticellosis and slight } \\
\text { damage caused by thrips. }\end{array}$ \\
\hline I & $\begin{array}{l}\text { Fruits at proper ripeness stage, intact and visibly healthy, free of insects, with a } \\
\text { fresh appearance and firm consistency; free of abnormal external moisture, odors, } \\
\text { flavors and foreign materials; free of damage to the epidermis by temperature; } \\
\text { fruits with pedicel }(<5 \mathrm{~cm}) \text { and with minimum values of pesticide residues. }\end{array}$ & $\begin{array}{l}\text { Superficial scratches from lenticellosis and } \\
\text { superficial scars caused by insects. These } \\
\text { must not exceed } 10 \% \text { of the epidermis. Fruit } \\
\text { deformations are accepted but should not } \\
\text { compromise the pulp. }\end{array}$ \\
\hline II & $\begin{array}{l}\text { Fruits at proper ripeness stage, intact and visibly healthy, free of insects, with a } \\
\text { fresh appearance and firm consistency; free of abnormal external moisture, odors, } \\
\text { flavors and foreign materials; free of damage to the epidermis by temperature; } \\
\text { fruits with pedicel }(<5 \mathrm{~cm}) \text { and with minimum values of pesticide residues. }\end{array}$ & $\begin{array}{l}\text { Defects in shape and color, external damage } \\
\text { caused by lenticellosis and insects. These } \\
\text { should not exceed } 10 \% \text { of the epidermis. }\end{array}$ \\
\hline Industrial & Fruit without pesticide residues that do not exceed the allowed limits. & $\begin{array}{l}\text { Fruit can have multiple defects but they } \\
\text { cannot compromise the pulp. }\end{array}$ \\
\hline
\end{tabular}

${ }^{1}$ Adapted from Icontec (2018) 
activation of the immune system and contribution to the treatment of diseases as relevant as cancer or HIV (Bouic, 2002).

Hass avocado from Colombia has the potential to capture new international consumers in terms of quantity and quality of fatty acids since fruits produced in the country's soil and climate conditions present comparative levels of these fatty acids to those reported worldwide (Tab 3).

On the other hand, organoleptic quality is related to the consumers' sensory perception when ingesting a product in terms of smell, taste, texture and visual aspects. In the case of hass avocado, fully ripe fruits with a dark purple epidermis color, slightly yellowish green pulp, a soft, creamy and even oily texture on the palate accompanied by nuances of nutty, fruity and herbal aromas and slightly sweet and not so bitter flavors are highly appreciated by international markets (Arpaia et al., 2018).

Ethical quality aspects are mainly related to the social influences of a productive system on a specific population. For example, a specific plant material cultivated by vulnerable populations such as single mothers who are heads of households or victims of the armed conflict with its respective traceability and certification could be a differentiating factor that generates added value for international altruistic markets (Gutjar et al., 2015).

Finally, the emotional aspects are related to the sensations that the customer perceives when buying or consuming a particular product. This aspect is mainly transcendental in the evolution of the avocado imaginary of consumption since its appearances on social networks such as Facebook, Instagram, and Twitter have increased in recent years. In addition, in other digital marketing platforms, avocados are being perceived as a symbol of "healthy life", social status or are even being related to graphic euphemisms of sexual connotation in the growing trend of "food porn" (McDonnell, 2016). The sensations at the time of buying, ingesting, photographing, publishing or displaying this product on the social web have generated a trend among the millennial population, which has resulted in the consolidation of aesthetic characteristics of fruits to be acquired. These characteristics will produce pleasure in people when sharing this fruit in their social environment, entertainment platforms and other networks (Ellstrand, 2018).

\section{Quality requirements depending on the target market}

Avocado fruit quality emphasizes the requirements of a given market, which is based on certain criteria such as (i) phytosanitary requirements, (ii) food safety, (iii) market accessibility, (iv) required quantities, and (v) value, etc. This implies a definition of quality in terms of trade and negotiation by the countries involved in commercial transitions. However, some aspects related to consumers and the characteristics of the product they demand have been forgotten. This has caused final consumers not to feel identified with

Table 3. Lipid profile of Hass avocado pulp reported in producer countries ${ }^{1}$.

\begin{tabular}{|l|c|c|c|c|c|c|}
\hline \multirow{2}{*}{ Fatty acid } & \multicolumn{5}{c|}{ Country (\% fatty acid-base) } \\
\cline { 3 - 8 } & & Australia & Mexico & New Zeland & United States & Colombia \\
\hline Palmitic acid & C16:0 & 25.63 & 22.59 & 20.61 & 22.24 & 16.81 \\
\hline Palmitoleic Acid & C16:1 & 7.29 & 11.63 & 10.31 & 13.14 & 7.85 \\
\hline Stearic Acid & C18:0 & 0.45 & 0.24 & 0.3 & 0.93 & 0.14 \\
\hline Oleic acid & C18:1 & 42.59 & 49.19 & 50.97 & 47.69 & 61.45 \\
\hline Linoleic acid & C18:2 & 20.87 & 14.72 & 16.1 & 14.47 & 4.37 \\
\hline$\alpha$ Linoleic Acid & C18:3 & 3.19 & 1.63 & 1.72 & 1.54 & 1.64 \\
\hline Sum of saturated fatty acids & & 26.07 & 22.83 & 20.91 & 23.16 & 16.96 \\
\hline Sum of monosaturated fatty acids & & 49.88 & 60.83 & 61.28 & 60.83 & 69.30 \\
\hline Sum of polyunsaturated fatty acids & & 24.06 & 16.35 & 17.81 & 16.01 & 13.94 \\
\hline Saturated/unsaturated ratio & & 0.35 & 0.29 & 0.26 & 0.30 & 0.20 \\
\hline
\end{tabular}

${ }^{1}$ Adapted from Tan et al. (2017) and Henao-Rojas et al. (2019). 
the product they are accessing since their imaginary of consumption is unknown to the value chain.

As described above, avocado consumption, especially the Hass variety, has been increasing since it has adequate flavor and functional properties because of its nutritional quality. That is why consumers will be the ones who largely define the concept of quality according to their preferences, which can be objective (nutritional content, shape, color, size, and texture, among others) or subjective (product origin, type of production system and its relationship with the environment, and form of commercialization, etc.) (Migliore et al., 2015, 2018; Bader et al., 2016).

In this regard, the most used criteria by consumers to select fruits at stores are associated with visual factors such as: (i) fruit weight (commercial size), (ii) shape (oval or pyriform), (iii) skin color (green, purple, black), (iv) skin texture (smooth or rough), and (v) absence of defects (for example, sunburn). On the other hand, the factors that are evaluated at the time of consumption are related to the internal quality of the fruit: (i) taste, (ii) pulp texture, (iii) pulp color, and (iv) seed size (Storey et al., 1973; Migliore et al., 2018). Additionally, it is reported that purchases are associated with fruit consumption habits, neophilia attitudes and various intrinsic and extrinsic quality attributes (attributes of particular and cultural beliefs) (Migliore et al., 2018).

In the case of Colombia, the particular quality requirements associated with intrinsic factors of avocado fruits according to export destinations or internal consumer preferences are not well known. In addition, there are no studies at the consumer level that show customer likes and quality criteria that could be implemented in order to improve fruit production, harvest, and post-harvest processes. In this regard, there are some parameters that were previously stated (Tab. 1 and 2) in the section related to harvest parameters or criteria, which refer to calibers and quality categorization (Icontec, 2018).

Marketing companies have a series of quality criteria based on characteristics such as chemical product residues, harvest time or ripening, visual defects caused by fruit deformities, mechanical damage or insects, and visible presence of pathologies (Ramírez-Gil et al., 2020). In addition, they carry out a rigorous process to define fruit quality and caliber (Tab. 1 and 2). It is important to state that fruits are rejected or accepted for export and/or national market according to damage, their origin, and affected area.

\section{PRE-HARVEST ASPECTS THAT DETERMINE THE QUALITY OF HASS AVOCADO AND MANAGEMENT PRACTICES CONDUCIVE TO IMPROVING QUALITY}

Avocado fruit quality is achieved in the crop as a result of the interaction among the genetics of the variety, environmental factors, the relationship between genotype and environment, the agronomic management of the crop and harvest criteria, among others (Ochoa, 2012; Schaffer et al., 2013; Ferreyra et al., 2016; Salazar-García et al., 2016b). Thus, fruit quality must start from a series of agronomic practices implemented at pre-harvest and harvest and must be complemented with adequate post-harvest work since, at this stage, fruit quality can only be maintained and not improved.

Environmental and edaphic variables and/or pre-harvest agronomic criteria that determine avocado fruit quality are highly variable and still little studied in each of the producer regions of the world. There is currently a trend to identify the specific characteristics of some areas in which better quality fruits are produced (Ferreyra et al., 2016).

The factors that affect avocado fruit quality include: environmental variables such as temperature, precipitation, solar brightness, relative humidity, and elevation, among others; edaphic properties associated with nutrient content (e.g. calcium, nitrogen and boron), texture, land slope, drainage networks, and nutrient ratios (e.g. N/Ca, K/Ca); the genetic material used as rootstock; crop management practices that include fertilization, planting density, pruning, irrigation, incidence of pests and diseases (e.g. avocado wilt complex), hormonal relationships (e.g. gibberellins), and leaf area index, among others (Ochoa, 2012; Bernal, 2016; Ferreyra et al., 2016; Salazar-García et al., 2016a; Ramírez-Gil et al., 2017; Ramírez-Gil, 2018b; Rivera et al., 2017; Novoa et al., 2018).

In Colombia, not much progress has been made in this regard and only a few studies have focused on the effect of altitude on the quantity and quality of fatty acids. As a result, it has been determined that, at a higher elevation, the concentration of fatty acids increases (Carvalho et al., 2015). In this regard, it is possible to increase fruit size percentage under these environmental conditions, which will also improve the extra quality percentages, pulp yield, and nutrient contents, among others (Bernal, 2016). However, limitations associated with lower yields and longer 
production cycles under these environmental conditions have to be considered (Bernal, 2016).

On the other hand, some studies have characterized exportable fruits in terms of physical and chemical variables, but have not made any contributions in terms of defining criteria to improve quality (Astudillo and Rodríguez, 2018). In this sense, some authors have determined how avocados that are produced under certain conditions in Colombia have good quality standards in terms of physical, chemical and nutritional variables (Henao-Rojas and Rodríguez, 2016; Rodriguez et al., 2018). However, it is reported that according to a scale from 1 to 10 by European importers, Colombian fruits obtained an average value of 5.9 based on three criteria: (i) ripening process (5.5), (ii) external quality (5.3), and (iii) internal quality (6.1). These values are much lower than the ones obtained by direct competitors such as Israel (6.8), Peru (7.1), South Africa (7.2) and Chile (7.4) (Analdex, 2017). This situation may be due to the great production system variability and the absence of a technological package for the country's conditions. For this reason, there is a need to unify the production criteria to improve fruit quality and thus increase producers' profitability levels.

It is important to understand that avocado fruit quality is the sum of the entire production process, which involves plant material suppliers, fruit producers, packers, distributors and consumers (Ochoa, 2012). That is why quality is a commitment of the entire value chain; in each link, all activities should be performed in the best way to ensure that Colombian fruit is positioned worldwide as a value brand and that the country is recognized for quality. This will allow Colombian fruits to continue conquering new market niches.

In general terms, there are a number of agronomic practices (Fig. 1) that producers can implement in their production systems with the objective of improving fruit quality. In this regard, a series of strategies has been evaluated in commercial plots under

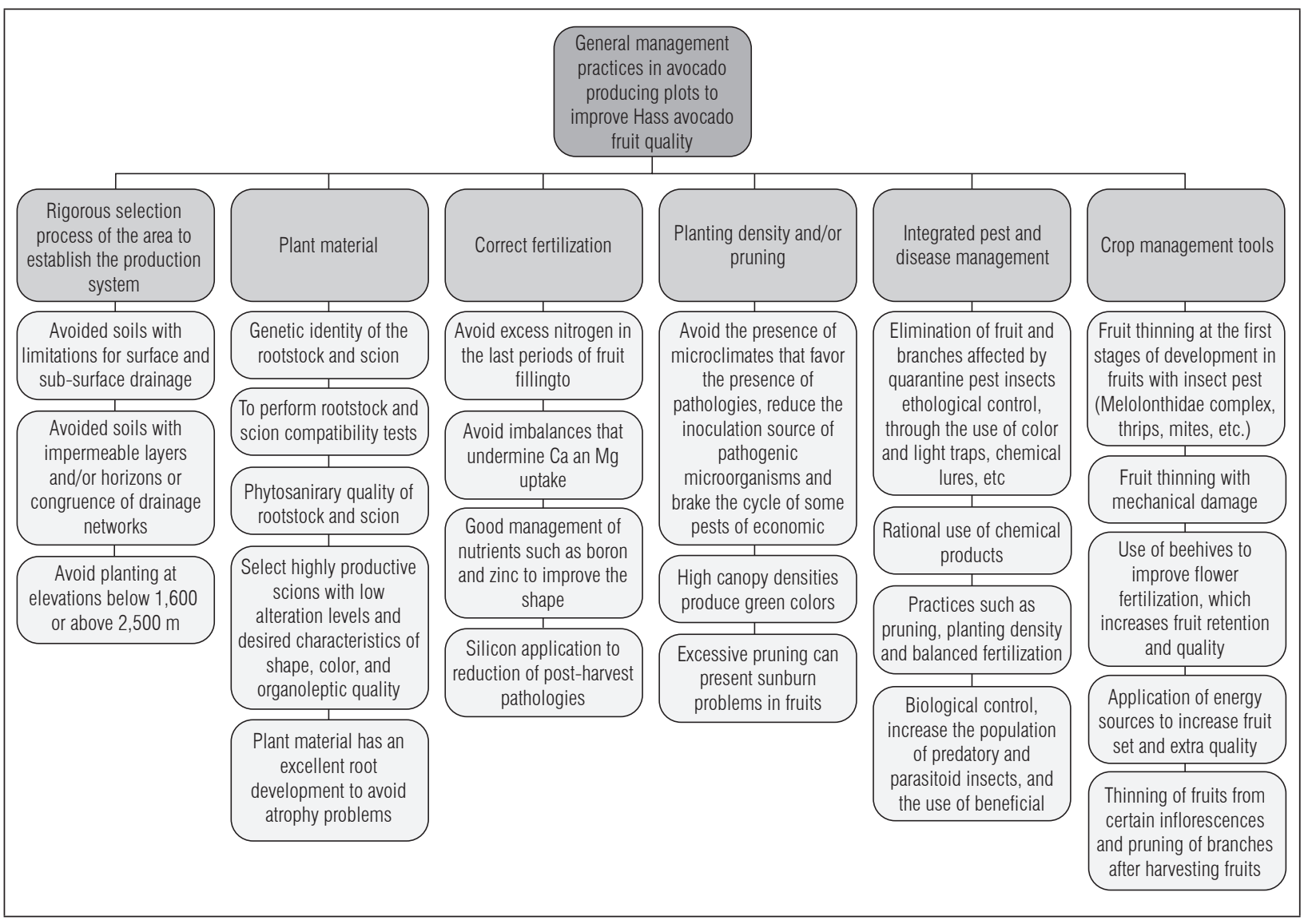

Figure 1. Basic pre-harvest agronomic practices that improve Hass avocado quality under conditions of the Colombian tropics. 
Colombian tropical conditions and reported by different scientific research with good results (see: Willingham et al., 2006; Everett et al., 2007; Crowley et al., 1996; Dann and Le, 2017; Kaluwa et al., 2010; Gazit, 1976; Ramírez-Gil, 2017; Carvalho et al., 2015; Henao-Rojas et al., 2019; Malhi et al., 2010; Bernal, 2016; Ramírez-Gil et al., 2018; Ramírez-Gil, 2013, 2018a; Ramírez-Gil and Morales-Osorio, 2018). As a result, more innocuous fruits with better calibers, less susceptibility to physiological disorders and postharvest pathologies, with outstanding sensory characteristics (color, shape, firmness, taste, etc.), higher nutrient levels, and longer shelf life have been obtained.

\section{HARVEST-ASSOCIATED ASPECTS THAT DETERMINE HASS AVOCADO QUALITY}

One of the global challenges the avocado industry has to face is offering the consumer a product with homogeneous ripening (Rivera et al., 2017). Avocado is a climacteric fruit that reaches consumption ripening several days after harvest (Hershkovitz et al., 2009). Ripening in this fruit is a highly complex process associated with multiple biochemical changes and hormonal relationships, which include increases in ethylene and respiration, loss of firmness, and development of sensory variables (taste and color), among others (Ochoa, 2009). This situation implies the need to identify harvest criteria with great influence on the avocado ripening processes and its quality in order to prevent the harvest of immature or overripe fruits and reduce post-harvest losses.

The first element for a correct harvest is the definition of harvest criteria. This decision should not only be based on a single indicator but on several criteria. This situation implies the need to use different harvest criteria designed among producers, packers, exporters, and traders, which must obey the target market and the desired shelf-life for the fruit. At present, there is a series of harvest indicators that are classified into destructive and non-destructive methods, which must be determined and calibrated per cultivar and at each producer region.

The mesocarp's oil content is considered to be the best avocado ripeness indicator (Lee, 1981; Ochoa, 2012). The minimum value for harvest should be $8 \%$ (Lee et al., 1983), but its determination is complex and expensive as it represents a high risk for operators, given that toxic organic solvents are used in the process (Lee et al., 1983; Ochoa, 2012). For this reason, dry matter has become the world's most widely used crop index since it is a simple, fast, and safe method and is highly correlated with the fatty acid content (Lee et al., 1983; Ochoa, 2012; Carvalho et al., 2014). On the other hand, there is currently a growing trend for the application of non-destructive techniques using a portable spectrometer. These techniques offer rapid results that are highly correlated with dry matter and mesocarp oils (Ncama et al., 2018).

In this regard, some advances have been made in Colombia, such as those reported by Carvalho et al. (2014) and Rodriguez et al. (2018), who determined that avocados must have a minimum of $23 \%$ dry matter at the time of harvest. This concept has become a misused criterion since it was the only parameter to determine the optimum harvest time without considering aspects such as shelf life, target market, and the differences of this variable according to environmental, agronomic and genotype parameters. This is why this indicator must be calibrated for the different avocado producing regions in Colombia and should be based on the importing market. The most commonly used crop indicators and their reference values for Colombia are described below.

Non-destructive methods use changes in fruit color and shape. Avocado fruit color changes depend on the ripening stage; fruits at early stages of development have a bright green color that later becomes opaque or dark green, and, at advanced ripening stages, they show a purple color that evolves to black. For fruit color, Ochoa (2012) reported a scale with values from 0 to 6 , which was calibrated based on fruit firmness and ripening process. Color 0 (opaque olive green) is equivalent to a hard firmness ( $>25$ lbs of pressure, harvest time), whereas a level 5 color (deep purple) is equivalent to fruit with soft firmness (5 lbs of pressure, ripe for consumption). Color can also be calibrated based on the ripeness level, and its measurement is taken with the use of tristimulus colorimetry (Henao-Rojas and Rodríguez, 2016). Additionally, in most varieties, the portion of the pedicel closest to the fruit turns yellowish and swollen, which is a good ripeness indicator. The skin structure must be rough with notorious lenticels, the seed must be separated from the pulp, and the pulp must have a green-yellowish color and creamy texture with transparent and removable tegument (Ochoa, 2012). In some situations, the size can also be a harvest indicator (Ochoa, 2012; Rodriguez et al., 2018). 
Firmness is a harvest criterion that is rarely used under field conditions; however, when used, it consists in quantifying the fruit hardness level (pounds of pressure). This parameter has been correlated with the ripening process in countries such as Mexico (Ochoa, 2012). Firmness can be measured by touch, but this technique is very subjective. For this reason, different devices such as the penetrometer or acoustic firmometer are used to determine this variable (Magwaza and Tesfay, 2015; Zhang et al., 2018), whose re-

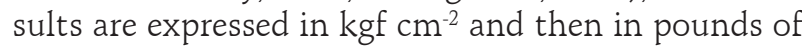
pressure (lbs). It is reported that the maximum and minimum values quantified in avocado skin at consumption ripeness for Colombia should be between 0.90 and $1.51 \mathrm{kgf} \mathrm{cm}^{-2}$ (Icontec, 2018).

Regarding destructive methods, the fatty acid profile is perhaps the method with the closest relationship with avocado fruit ripening, but it presents multiple disadvantages, such as its cost and the difficulty to obtain oil extracts, as described above (Lee, 1981; Ochoa, 2012). For Colombia, the oil content for harvest must be a minimum of $12 \%$ in mass fraction (Icontec, 2018). On the other hand, the most used harvest indicator in Colombia is dry matter, and it is recommended to harvest fruits when this parameter is equal to or higher than 23\% (Icontec, 2018). However, Carvalho et al. (2015) and Rodriguez et al. (2018) reported that the dry matter content for harvest in the Department of Antioquia ranges between 22 and $26 \%$ as a base for a minimum oil percentage of $11.2 \%$. Another indicator used is the minimum pulp percentage, which must be a minimum of $58 \%$ for consumption ripeness (Icontec, 2018).

Once the harvest criterion is defined, a pesticide residue analysis must be carried out a month before the harvest (Icontec, 2018). This test determines if the presence of pesticide residues is below the maximum limits allowed according to the regulations of the importing country. These criteria are different according to the destination, and the European Union establishes its own criteria just as the US market does.

A correct harvest is carried out after the harvest criteria have been selected and calibrated and the pesticide residue test has been performed. The process is carried out avoiding mechanical damage, which affects the cosmetic appearance of fruits or can be the gateway to pathogens that cause postharvest diseases.

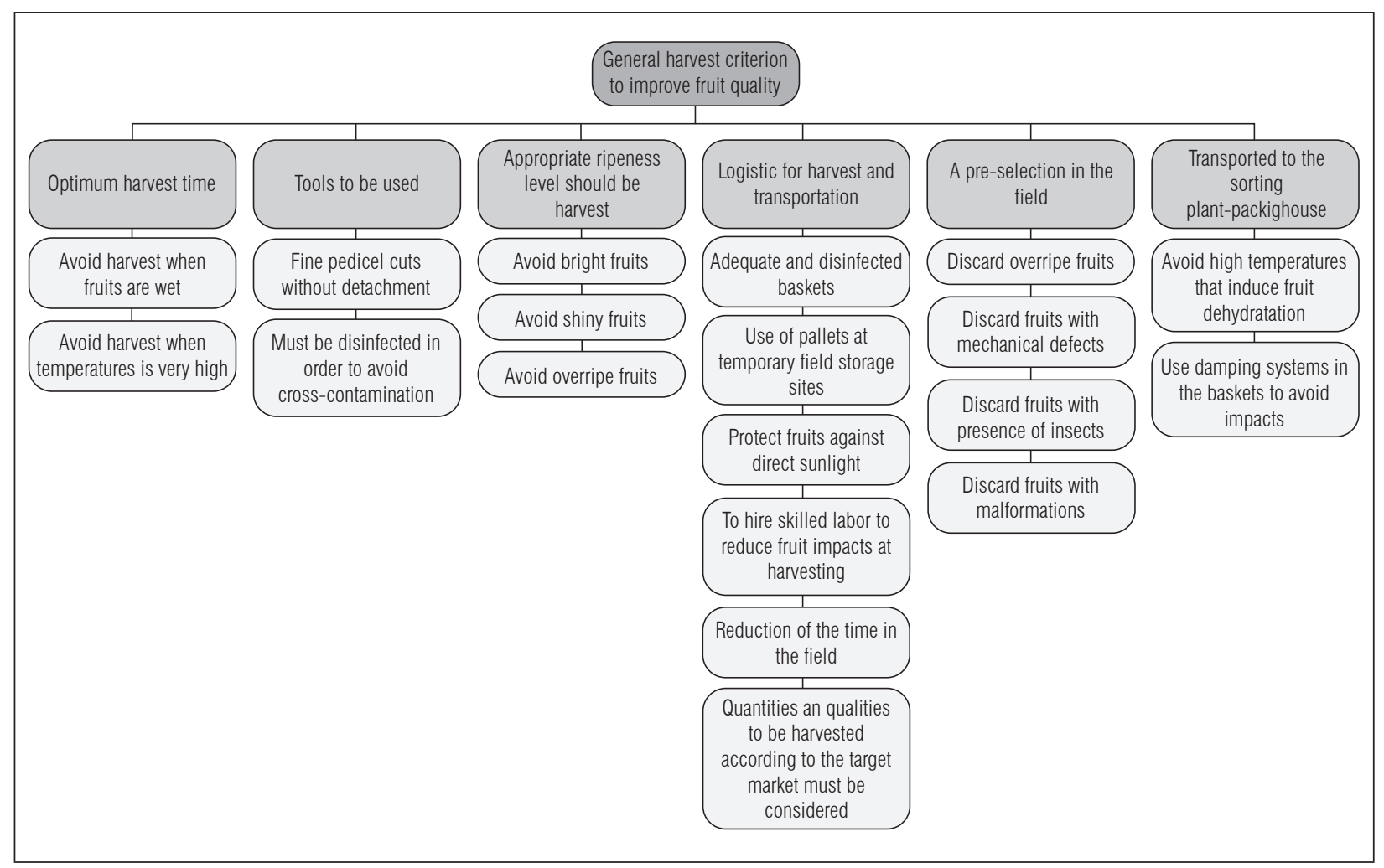

Figure 2. Main harvest practices associated with the preservation of Hass avocado quality. 
It is also recommended to handle fruits according to the criteria of the international code of practice general principles of food hygiene (CAC/RCP, 1-1969, Rec. 3-1997). In addition, the microbiological requirements defined in the legislation according to the principles for the establishment and application of microbiological criteria for foods (CAC/GL 21-1997) must be followed (Icontec, 2018).

An adequate harvest involves the following parameters reported in figure 2 (see: Duvenhage, 1993; Ramírez-Gil, 2018b; Perkins et al., 2019).

Conflict of interest: this manuscript was prepared and reviewed with the participation of all authors, who declare that there exists no conflict of interest that that puts at risk the validity of the presented results.

\section{BIBLIOGRAPHIC REFERENCES}

Analdex. 2017. Los retos del aguacate Hass Colombiano en los mercados internacionales. Armenia, Colombia.

Araújo, R.G., R.M. Rodriguez-Jasso, H.A. Ruiz, M.M.E. Pintado, and C.N. Aguilar. 2018. Avocado by-products, nutritional and functional properties. Trends Food Sci. Technol. 80, 51-60. Doi: 10.1016/j.tifs.2018.07.027

Arpaia, M.L., S. Collin, J. Sievert, and D. Obenland. 2018. 'Hass' avocado quality as influenced by temperature and ethylene prior to and during final ripening. Postharvest Biol. Technol. 140, 76-84. Doi: 10.1016/j. postharvbio.2018.02.015

Astudillo, C. and P. Rodriguez. 2018. Parámetros fisicoquímicos del aguacate Persea americana Mill. cv. Hass (Lauraceae) producido en Antioquia (Colombia) para exportación. Corpoica Cienc. Tecnol. Agropecuaria 19, 383-392. Doi: 10.21930/rcta.vol19 num2 art:694

Bader, H., A. Ariyawardana, and R. Collins. 2016. Capturing consumer preferences for value chain: improvements in the Mango Industry of Pakistan - AgEcon Search, International. Int. Food Agribus. Man. 18(3), 123-148.

Bernal, J. 2016. Estudios ecofisiológicos en aguacate cv. Hass en diferentes ambientes como alternativa productiva en Colombia. PhD thesis. Universidad Nacional de Colombia. Medellin, Colombia.

Botero, C.M.R. and M.O.R. Morales. 2018. Sobre los alimentos con actividad hipolipemiante. Rev. Cuba. Aliment. Nutr. 28(2), 417-456.

Bouic, P.J.D. 2002. Sterols and sterolins: new drugs for the immune system? Drug Discov. Today. 7(14), 775-778. Doi: 10.1016/S1359-6446(02)02343-7
Carvalho, C.P., M.A. Velásquez, and Z.V. Rooyen. 2014. Determination of the minimum dry matter index for the optimum harvest of "Hass" avocado fruits in Colombia. Agron. Colomb. 32(3), 399-406. Doi: 10.15446/ agron.colomb.v32n3.46031

Carvalho, C.P., J. Bernal-Estrada, M.A. Velásquez, and J.R. Cartagena-Valenzuela. 2015. Fatty acid content of avocados (Persea americana Mill. cv. Hass) in relation to orchard altitude and fruit maturity stage. Agron. Colomb. 33 (2), 220-227. Doi: 10.15446/agron.colomb.v33n2.49902

Crowley, D.E., W. Smith, B. Faber, and J.A. Manthey. 1996. Zinc fertilization of avocado trees. HortScience 31(2), 224-229. Doi: 10.21273/HORTSCI.31.2.224

Dann, E.K., and D.P. Le. 2017. Effects of silicon amendment on soilborne and fruit diseases of avocado. Plants 6(4), 51. Doi: 10.3390/plants6040051

Duarte, P.F., M.A. Chaves, C.D. Borges, C.R.B. Mendonça, P.F. Duarte, M.A. Chaves, C.D. Borges, and C.R.B. Mendonça. 2016. Avocado: characteristics, health benefits and uses. Cienc. Rural. 46(4), 747-754. Doi: 10.1590/0103-8478cr20141516

Duvenhage, J. 1993. The influence of wet picking on post harvest diseases and disorders of avocado fruit. South African Avocado Growers` Association Yearbook 16, 77-79.

Ellstrand, N. 2018. Sex on the kitchen table: the romance of plants and your food. University of Chicago Press, Chicago, IL. Doi: 10.7208/ chicago/9780226574929.001.0001

Everett, K.R, L.M. Boyd, H.A. Pak, and J.G.M. Cutting. 2007. Calcium, fungicide sprays and canopy density influence postharvest rots of avocado. Australas. P1. Pathol. 36(1), 22-31. Doi: 10.1071/AP06076

Ferreyra, R., G. Sellés, J. Saavedra, J. Ortiz, C. Zúñiga, C. Troncoso, S.A. Rivera, M. González-Agüero, and B.G. Defilippi. 2016. Identification of pre-harvest factors that affect fatty acid profiles of avocado fruit (Persea americana Mill) cv. 'Hass' at harvest. S. African J. Bot. 104, 15-20. Doi: 10.1016/j.sajb.2015.10.006

Fulgoni, V.L., M. Dreher, and A.J. Davenport. 2013. Avocado consumption is associated with better diet quality and nutrient intake, and lower metabolic syndrome risk in US adults: results from the National Health and Nutrition Examination Survey (NHANES) 20012008. Nutr. J. 12(1). Doi: 10.1186/1475-2891-12-1

Gazit, S. 1976. Pollination and fruit set of avocado. pp. 88-92. In: Sauls, J.W., R.L. Phillips, and L.K. Jackson (eds.). Proc. $1^{\text {st }}$ Int. Tropical Fruit Short Course: The Avocado. University of Florida, Gainesville, FL.

Gutjar, S., C. de Graaf, V. Kooijman, R.A. de Wijk, A. Nys, G.J. ter Horst, and G. Jager. 2015. The role of emotions in food choice and liking. Food Res. 76, 216-223. Doi: 10.1016/j.foodres.2014.12.022 
Henao-Rojas, J. and P. Rodríguez. 2016. Evaluation of color during avocado (Persea americana Mill. cv. Hass) ripening. Agron Colomb. 31(1), 876-879.

Henao-Rojas, J.C., J.H. Lopez, N.W. Osorio, and J.G. Ramírez-Gil. 2019. Fruit quality in Hass avocado and its relationships with different growing areas under tropical zones. Rev. Ceres 66(5), 341-350. Doi: 10.1590/0034-737x201966050003

Hershkovitz, V., H. Friedman, E.E. Goldschmidt, O. Feygenberg, and E. Pesis. 2009. Induction of ethylene in avocado fruit in response to chilling stress on tree. Plant Physiol. 166(17), 1855-1862. Doi: 10.1016/j. jplph.2009.05.012

Icontec, Instituto Colombiano de Normas Técnicas y Certificación. 2018. Frutas frescas aguacate variedad has, especificaciones. Bogota.

Kaluwa, K., I. Bertling, J. Bower, and Z. Tesfay, 2010. Silicon application effects on 'Hass' avocado fruit physiology. South African Avocado Growers: Association Yearbook. 33, 44-47.

Lee, S.K. 1981. A review and background of the avocado maturity standard, Yearbook. California Avocado Society. 40(1), 55-63.

Lee, S.K., R.E. Young, P.M. Schiffman, and C.W. Coggins, 1983. Maturity studies of avocado fruit based on picking dates and dry weigth. J. Am. Soc. Hortic. Sci. 108, 390-394.

Liverani, A., G. Caligiana, L. Frizziero, D. Francia, G. Donnici, and K. Dhaimini. 2019. Design for Six Sigma (DFSS) for additive manufacturing applied to an innovative multifunctional fan. Int. J. Interact. Des. Manuf. 13(1), 309-330. Doi: 10.1007/s12008-019-00548-9

Lottenberg, A.M.P., V.S. Nunes, E.R. Nakandakare, M. Neves, M. Bernik, J.E. Santos, and E.C.R. Quintão. 2002. Plant sterol ester efficiency on the plasma lipid reduction in moderate hipercholesterolemic subjects. Arq. Bras. Cardiol. 79(2), 139-142. Doi: 10.1590/ S0066-782X2002001100005

Magwaza, L.S. and S.Z. Tesfay. 2015. A review of destructive and non-destructive methods for determining avocado fruit maturity. Food Bioproc. Tech. 8 (10), 1995-2011. Doi: 10.1007/s11947-015-1568-y

Malhi, Y., M. Silman, N. Salinas, M. Bush, P. Meir, and S. Saatchi, 2010. Elevation gradients in the tropics: laboratories for ecosystem ecology and global change research. Glob. Change Biol. 16(12), 3171-3175. doi: 10.1111/j.1365-2486.2010.02323.x

McDonnell, E.M. 2016. Food porn: the conspicuous consumption of food in the age of digital reproduction. pp. 239-265. In: Bradley, P. (ed.). Food, media and contemporary culture, the edible image. Palgrave Macmillan, London. Doi: 10.1057/9781137463234_14

Migliore, G., A. Galati, P. Romero, M. Crescimanno, and G. Schifani. 2015. Quality attributes of cactus pear fruit and their role in consumer choice: the case of Italian consumers. Brit. Food J. 176(6), 1637-1651. Doi: 10.1108/BFJ-04-2014-0147

Migliore, G., V. Farina, G. Guccione, and G. Schifani, 2018. Quality determinants of avocado fruit consumption in italy. Implications for small farms. Food Safety Manage. 19(163), 148-153.

MADR, Ministerio de Agricultura y Desarrollo Rural de Colombia. 2018. Cadena de aguacate, Indicadores e Instrumentos. Bogota.

Ncama, K., L.S. Magwaza, C.A. Poblete-Echeverría, H.H. Nieuwoudt, S Z. Tesfay, and A. Mditshwa. 2018. On-tree indexing of 'Hass' avocado fruit by non-destructive assessment of pulp dry matter and oil content. Biosyst. Eng. 174, 41-49. Doi: 10.1016/j. biosystemseng.2018.06.011

Novoa, M.A., D. Miranda, and L.M. Melgarejo. 2018. Efecto de las deficiencias y excesos de fósforo, potasio y boro en la fisiología y el crecimiento de plantas de aguacate (Persea americana cv. Hass). Rev. Colomb. Cienc. Hortic. 12(2), 293-307. Doi: 10.17584/rcch.2018v12i2.8092

Obenland, D., S. Collin, J. Sievert, F. Negm, and M.L. Arpaia, 2012. Influence of maturity and ripening on aroma volatiles and flavor in 'Hass' avocado. Postharvest Biol. Technol. 71, 41-50. Doi: 10.1016/j. postharvbio.2012.03.006

Ochoa, S. 2009. Calidad y manejo pos-cosecha del fruto de aguacate. pp. 1-17. In: III Congreso Latinoamericano del Aguacate. Medellin, Colombia.

Ochoa, S. 2012. Calidad pos-cosecha del fruto de aguacate Hass. pp. 1-30. In: IV Encuentro Nacional de la Cadena Productiva del Aguacate. Politécnico Colombiano Jaime Isaza Cadavid Medellín, Medellin, Colombia.

Orjuela-Castro, J., F. Morales-Aguilar, and L. Mejía-Flórez. 2017. خCuál es la mejor cadena de suministro para frutas perecederas, lean o ágil?. Rev. Colomb. Cienc. Hortíc. 11(2), 294-305. Doi: 10.17584/rcch.2017v11i2.5950

Perkins, M.L., D.C. Joyce, and L.M. Coates. 2019. Possible contribution of impact injury at harvest to anthracnose expression in ripening avocado: A review. Sci. Hortic. 246, 785-790. Doi: 10.1016/j.scienta.2018.11.012

Prieto, M., J.M. Mouwen, S.L. Puente, and A.C. Sánchez. 2008. Concepto de calidad en la industria agroalimentaria. Interciencia 33(4), 258-264.

Ramírez-Gil, J. 2013. Incidencia, diagnóstico, comportamiento y alternativas de manejo de la marchitez del aguacate con énfasis en Phytophthora cinnamomi Rands. $\mathrm{MsC}$ thesis. Universidad Nacional de Colombia, Medellin, Colombia.

Ramírez-Gil, J.G. 2017. Calidad del fruto de aguacate con aplicaciones de ANA, boro, nitrógeno, sacarosa y anillado. Mesoam. Agron. 28(3), 591-603. Doi: 10.15517/ ma.v28i3.23688 
Ramírez-Gil, J.G., J.G. Morales, and A.T. Peterson. 2018. Potential geography and productivity of "Hass" avocado crops in Colombia estimated by ecological niche modeling. Sci. Hortic. 237, 287-295. Doi: 10.1016/j. scienta.2018.04.021

Ramírez-Gil, J.G. and J.G. Morales-Osorio. 2018. Microbial dynamics in the soil and presence of the avocado wilt complex in plots cultivated with avocado cv. Hass under ENSO phenomena (El Niño - La Niña). Sci. Hortic. 240, 273-280. Doi: 10.1016/j.scienta.2018.06.047

Ramírez-Gil, J. 2018a. Avocado wilt complex disease, implications and management in Colombia. Rev. Fac. Nac. Agron. Medellin 71(2), 8525-8541. Doi: 10.15446/ rfna.v71n2.66465

Ramírez-Gil, J. 2018b. Sustainable development of avocado cv Hass crop based on knowledge and management of its mayor pathologies and the spatial and climatic variability of production areas. $\mathrm{PhD}$ thesis. Universidad Nacional de Colombia, Medellin, Colombia.

Ramírez-Gil, J.G., E. Gilchrist R., and J.G. Morales O. 2017. Economic impact of the avocado (cv. Hass) wilt disease complex in Antioquia, Colombia, crops under different technological management levels. Crop Prot. 101, 103-115. Doi: 10.1016/j.cropro.2017.07.023

Ramírez-Gil, J.G., J.H. López, and J.C. Henao-Rojas. 2020. Causes of Hass avocado fruit rejection in preharvest, harvest, and packinghouse: economic losses and associated variables. Agronomy 10(1), 8. Doi: 10.3390/ agronomy10010008

Rivera, S.A., R. Ferreyra, P. Robledo, G. Selles, M.L. Arpaia, J. Saavedra, and B.G. Defilippi. 2017. Identification of preharvest factors determining postharvest ripening behaviors in 'Hass' avocado under long term storage. Sci Hortic. 216, 29-37. Doi: 10.1016/j. scienta.2016.12.024

Rodriguez, P., J.C. Henao, G. Correa, and A. Aristizabal. 2018. Identification of harvest maturity indicators for 'Hass' avocado adaptable to field conditions. HortTechnol. 28(6), 815-821. Doi: 10.21273/ HORTTECH04025-18

Salazar-García, S., R.E. Medina-Carrillo, and A. Álvarez-Bravo. 2016a. Influencia del riego y radiación solar sobre el contenido de fitoquímicos en la piel de frutos de aguacate 'Hass'. Rev. Mex. Cienc. Agric. 13, $2565-$ 2575. Doi: 10.29312/remexca.v0i13.483

Salazar-García, S., R.E. Medina-Carrillo, and A. Álvarez-Bravo. 2016b. Evaluación inicial de algunos aspectos de calidad del fruto de aguacate 'Hass' producido en tres regiones de México. Rev. Mex. Cienc. Agric. 7(2), 277-289. Doi: 10.29312/remexca.v7i2.343

Sarkar, R., I. Podder, N. Gokhale, S. Jagadeesan, and V.K. Garg. 2017. Use of vegetable oils in dermatology: an overview. Int. J. Dermatol. 56 (11), 1080-1086. Doi: 10.1111/ijd.13623

Schaffer, B., B.N. Wolstenholme, and A.W. Whiley (eds.). 2013. The avocado: botany, production and uses. CABI, Cambridge, MA. Doi: 10.1079/9781845937010.0000

Serpa, A., L. Echeverri, M. Lezcano, L. Vélez, A. Ríos, and G. Hincapie. 2014. Extracción de aceite de aguacate variedad "Hass" (Persea americana Mill) liofilizado por prensado en frio. Rev. Invest. Aplic. 8(2), 113-123.

Singels, J., G. Ruël, and H. van de Water. 2001. ISO 9000 series - Certification and performance. Int. J. Qual. Reliab. Manag. 18(1), 62-75. Doi: 10.1108/02656710110364477

Storey, W., B. Bergh, and R. Whitsell, 1973. Factors affecting the marketability of avocado fruit. California Avocado Society Yearbook 57, 33-39.

Tan, C.X., S.S. Tan, and S.T. Tan. 2017. Influence of geographical origins on the physicochemical properties of Hass avocado oil. J. Amer. Oil Chem. Soc. 94(12), 1431-1437. Doi: 10.1007/s11746-017-3042-7

Willingham, S.L., K.G. Pegg, J.M. Anderson, A.W. Cooke, J.R. Dean, F.R. Giblin, and L.M. Coates. 2006. Effects of rootstock and nitrogen fertiliser on postharvest anthracnose development in Hass avocado. Australas. P1. Pathol. 35(6), 619-629. Doi: 10.1071/AP06062

Zhang, H., J. Wu, Z. Zhao, and Z. Wang. 2018. Nondestructive firmness measurement of differently shaped pears with a dual-frequency index based on acoustic vibration. Postharvest Biol. Technol. 138, 11-18. Doi: 10.1016/j.postharvbio.2017.12.002 